\title{
KEMAMPUAN VARIABEL AKUNTANSI DAN NON AKUNTANSI DALAM MEMPREDIKSI BOND RATING DI INDONESIA
}

\author{
Marfuah \\ Fakultas Bisnis dan Ekonomika Universitas Islam Indonesia \\ marfuah@uii.ac.id \\ Berlyana Permatasari \\ Fakultas Bisnis dan Ekonomika Universitas Islam Indonesia \\ berlyanapermatasari123@gmail.com \\ Selfira Salsabilla \\ Fakultas Bisnis dan Ekonomika Universitas Islam Indonesia \\ selfirasalsabilla@uii.ac.id
}

\begin{abstract}
Abstrak: Kemampuan Variabel Akuntansi dan Non Akuntansi dalam Memprediksi Bond Rating di Indonesia. Tujuan penelitian ini adalah untuk menguji kemampuan variabel akuntansi dan non akuntansi dalam memprediksi peringkat obligasi pada perusahaan non keuangan di Indonesia. Variabel akuntansi dalam penelitian ini meliputi produktivitas, profitabilitas, solvabilitas, likuiditas, dan leverage. Sedangkan variabel non akuntansi terdiri dari jaminan obligasi, umur obligasi, dan reputasi auditor. Sampel dalam penelitian ini adalah perusahaan non keuangan yang terdaftar di Bursa Efek Indonesia (BEI) selama tahun 2013-2016 dan diperingkat oleh PT Pefindo. Dengan menggunakan metode purposive sampling, dipilih 120 sampel obligasi. Pengujian hipotesis dilakukan dengan menggunakan analisis regresi logistik ordinal. Hasil pengujian hipotesis menunjukkan bahwa solvabilitas terbukti berpengaruh positif signifikan terhadap peringkat obligasi, sedangkan leverage terbukti berpengaruh negatif signifikan terhadap peringkat obligasi. Likuiditas dan umur obligasi memiliki pengaruh yang signifikan terhadap peringkat obligasi tetapi dengan hasil yang berlawanan dengan arah prediksi. Artinya likuiditas berpengaruh negatif signifikan terhadap peringkat obligasi, sedangkan umur obligasi berpengaruh positif signifikan terhadap peringkat obligasi. Variabel produktivitas, profitabilitas, likuiditas, jaminan obligasi, dan reputasi auditor tidak berpengaruh signifikan terhadap prediksi peringkat obligasi.
\end{abstract}

Kata kunci: variabel akuntansi, variabel non akuntansi, reputasi auditor, dan peringkat obligasi

Abstract: The Ability of Accounting and Non Accounting Variables in Predicting Bond Rating in Indonesia. The purpose of this study is to test the ability of accounting and non-accounting variables in predicting bond ratings of non-financial companies in Indonesia. The accounting variables in this study include productivity, profitability, solvency, liquidity, and leverage. Meanwhile, the nonaccounting variables consist of bond guarantees, age of bonds, and auditor reputation. The sample in this study were non-financial companies listed on the Indonesia Stock Exchange (BEI) during 20132016 and rated by PT Pefindo. By using purposive sampling method, 120 bond samples were selected. Hypothesis testing is done using ordinal logistic regression analysis. The results of hypothesis testing show that solvency is proven to have a significant positive effect on bond ratings, while leverage is proven to have a significant negative effect on bond ratings. The liquidity and life of the bonds have a significant effect on the rating of the bonds but with the results in the opposite direction to the prediction. This means that liquidity has a significant negative effect on the bond rating, while the age of the bond has a significant positive effect on the bond rating. The variables of productivity, profitability, liquidity, bond guarantees, and auditor reputation do not significantly influence the prediction of bond ratings

.Keywords: accounting variable, non accounting variable, auditor's reputation, and bond rating 


\section{PENDAHULUAN}

Salah satu faktor penting dalam menjalankan suatu usaha adalah sumber pembiayaan bagi usaha tersebut. Menerbitkan obligasi merupakan salah satu bentuk pembiayaan atau pendanaan yang dapat dilakukan oleh suatu perusahaan. Sari \& Badjra (2016) menyatakan bahwa investasi obligasi itu lebih aman, akan tetapi obligasi tetap memiliki risiko yaitu risiko tingkat suku bunga dan risiko perusahaan tidak mampu membayar kupon obligasi atau nilai pokok hutang obligasinya. Pemeringkatan obligasi merupakan salah satu cara untuk meminimalisir risiko obligasi.

Susilowati \& Sumarto berpendapat bahwa memperhatikan peringkat obligasi sangat penting, khususnya untuk pemilik modal yang akan melakukan investasi. Informasi yang diperoleh dari peringkat obligasi mempunyai tujuan untuk menilai kualitas kredit dan kinerja dari perusahaan penerbit. Peringkat obligasi tersebut merupakan salah satu acuan dari investor ketika akan memutuskan untuk membeli suatu obligasi perusahaan atau tidak. Widiyastuti, Djumahir, \& Khusniyah (2014) menjelaskan bahwa selain peringkat obligasi memiliki manfaat bagi investor, peringkat obligasi ini juga memiliki manfaat bagi perusahaan penerbit obligasi yaitu untuk menunjukkan penilaian atas keamanan dari obligasi yang diberikan.

Di Indonesia, terdapat 3 (tiga) lembaga pemeringkat obligasi, yaitu PT Pefindo, PT Kasnic Credit Rating Indonesia, dan PT Fitch Ratings Indonesia. Penelitian fokus pada obligasi yang diperingkat oleh lembaga pemeringkat PT Pefindo karena sebagian besar perusahaan yang terdaftar di Bursa Efek Indonesia menggunakan jasa pemeringkatan PT Pefindo.

Widiyastuti (2016) menyatakan bahwa peringkat obligasi diperbaharui secara reguler, perbaruan dari peringkat obligasi ini berguna untuk mencerminkan perubahan signifikan dari kinerja keuangan dan bisnis perusahaan. Perubahan peringkat obligasi memiliki pengaruh signifikan pada aktivitas investasi dan pendanaan masa depan perusahaan serta profil risiko dan kinerja masa depannya.

Salah satu kasus terjadi pada PT Express Transindo Utama Tbk yang mengalami gagal dalam membayar bunga ke-15 obligasi I Tahun 2014 senilai Rp 1 triliun, padahal awalnya obligasi tersebut mempunyai peringkat A dari Pefindo. Kemudian PT Pefindo kembali menurunkan peringkat obligasi I tahun 2014 dari BB- menjadi D atau default. Hal ini terjadi karena PT Express Transindo Utama Tbk gagal membayar bunga pada 26 Maret 2018. Gagal 


\section{Nominal: Barometer Riset Akuntansi dan Manajemen}

P-ISSN: 2303-2065 E-ISSN: 2502-5430

Volume 10 No 1 (2021)

membayar hutang terjadi ketika pertama kali tidak membayar kupon bunga (Melani, 2016).

Fenomena yang terjadi di Indonesia perihal peringkat obligasi dari beberapa perusahaan yang mengalami gagal bayar (default) yang kebetulan memiliki peringkat investment-grade ini menimbulkan suatu pertanyaan apakah peringkat obligasi yang dinilai oleh lembaga pemeringkat di Indonesia akurat atau tidak. Realitas yang terjadi adalah peringkat obligasi suatu perusahaan tidak selalu stabil. Keadaan fluktuatif atau kondisi naik turunnya peringkat obligasi ini disebabkan oleh berbagai faktor, baik faktor akuntansi maupun faktor non akuntansi. Pengaruh faktor akuntansi dan faktor non akuntansi dalam kaitannya dengan bond rating didukung oleh penelitian sebelumnya yang sudah dilakukan.

Rusfika \& Wahidahwati (2017), Sari \& Badjra (2016), dan Widowati, Nugrahanti, \& Kristanto (2013) menyatakan bahwa terdapat banyak faktor yang mempengaruhi peringkat obligasi baik dari faktor akuntansi maupun non akuntansi. Faktor akuntansi meliputi rasio produktivitas, likuiditas, solvabilitas, profitabilitas, dan leverage. Faktor non akuntansi meliputi jaminan, reputasi auditor dan umur obligasi. Oleh karena adanya hasil yang tidak konsisten dalam penelitianpenelitian sebelumnya, maka diperlukan penelitian lebih lanjut untuk menguji kembali pengaruh faktor akuntansi dan non akuntansi terhadap bond rating.

Penelitian ini menguji faktor-faktor yang berpengaruh terhadap peringkat obligasi pada perusahaan non keuangan yang terdaftar di Bursa Efek Indonesia ditinjau dari faktor akuntansi dan non akuntansi. Faktor akuntansi yang digunakan dalam penelitian ini adalah produktivitas, profitabilitas, solvabilitas, likuiditas, dan leverage. Sedangkan faktor non akuntansi terdiri dari jaminan obligasi, umur obligasi, dan reputasi auditor. Penelitian ini menjadi penting karena kandungan informasi akuntansi dan non akuntansi merupakan acuan utama dalam mempertimbangkan untuk memprediksi bond rating. Berdasarkan latar belakang tersebut, penelitian ini bertujuan untuk mengetahui kemampuan variabel akuntansi dan non akuntansi dalam memprediksi peringkat obligasi pada perusahaan non keuangan di Indonesia.

\section{KAJIAN LITERATUR}

\section{Singnaling Theory}

Signalling Theory menjelaskan adanya asimetri informasi antara pihak yang berkepentingan dalam perusahaan karena terdapat pihak yang memiliki informasi lebih baik daripada pihak lainnya (Spence, 1973). Sebagai contoh, informasi terkait peringkat obligasi maka manajemen perusahaan 


\section{Nominal: Barometer Riset Akuntansi dan Manajemen}

P-ISSN: 2303-2065 E-ISSN: 2502-5430

Volume 10 No 1 (2021)

dianggap mempunyai informasi yang lebih baik dibanding pihak lainnya. Henny (2016) mengatakan bahwa dengan adanya asimetri informasi, sangat sulit bagi investor dan kreditur untuk membedakan antara perusahaan yang mempunyai kualitas tinggi dengan perusahaan berkualitas rendah.

\section{Variabel Akuntansi dan Peringkat Obligasi}

Produktivitas merupakan rasio yang mengukur seberapa efektif perusahaan menggunakan sumber daya yang dimiliki oleh perusahaan tersebut (Widowati et al., 2013). Rusfika \& Wahidahwati (2017) menjelaskan jika produktivitas perusahaan tinggi kemungkinan obligasi yang diterbitkan perusahaan termasuk kelompok investment grade. Perusahaan dengan tingkat produktivitas tinggi berarti tingkat penjualan juga tinggi sehingga akan meningkatkan kemampuan perusahaan menghasilkan laba. Kemampuan menghasilkan laba yang tinggi ini pada gilirannya akan meningkatkan kemampuan perusahaan dalam memenuhi kewajibannya sehingga akan mendorong diperolehnya peringkat obligasi yang tinggi yaitu investment grade. Penelitian Henny (2016) menemukan bahwa produktivitas berpengaruh positif terhadap prediksi peringkat obligasi.

H1. Produktivitas berpengaruh positif terhadap prediksi peringkat peringkat obligasi.
Profitabilitas memberikan gambaran sejauh manakah keefektifan perusahaan dalam menghasilkan laba. Tingkat profitabilitas yang tinggi dapat mengindikasikan kemampuan perusahaan untuk going concern dan memenuhi kewajibannya. Laba perusahaan dapat digunakan untuk melunasi kewajiban perusahaan termasuk obligasi. Dengan demikian tingkat profitabilitas dapat digunakan sebagai pengukur risiko default perusahaan. Hasil penelitian Amalia (2013), Rusfika \& Wahidahwati (2017), dan Widowati et al., (2013) menemukan bahwa variabel profitabilitas yang diproksikan dengan Return on Assets berpengaruh positif terhadap peringkat obligasi di PT Pefindo.

H2. Profitabilitas berpengaruh positif terhadap prediksi peringkat obligasi.

Solvabilitas merupakan kemampuan perusahaan membayar semua kewajiban atau utang-utangnya baik jangka pendek maupun jangka panjang (Rusfika \& Wahidahwati, 2017). Teori sinyal menjelaskan bahwa investor menerima sinyal informasi perusahaan berdasarkan laporan keuangan yang disampaikan oleh manajemen. Informasi dari laporan keuangan yang bisa digunakan sebagai tanda untuk menilai bahwa perusahaan mempunyai kemampuan yang baik atau buruk dalam melunasi kewajiban jangka panjang dan jangka 


\section{Nominal: Barometer Riset Akuntansi dan Manajemen}

P-ISSN: 2303-2065 E-ISSN: 2502-5430

Volume 10 No 1 (2021)

pendeknya adalah informasi tentang arus kas dari operasi. Apabila solvabilitas tinggi maka kemungkinan obligasi tersebut masuk pada investment grade, karena dengan keadaan tersebut perusahaan mempunyai kemampuan untuk melunasi segala kewajibannya tepat waktu. Rusfika \& Wahidahwati (2017) dan Widowati et al. (2013) menunjukkan bahwa solvabilitas berpengaruh positip signifikan terhadap peringkat obligasi.

H3. Solvabilitas berpengaruh positif terhadap prediksi peringkat obligasi.

Likuiditas mencerminkan tingkat kemampuan perusahaan untuk melunasi kewajiban jangka pendeknya. Tingkat rasio likuiditas yang tinggi mengindikasikan bahwa perusahaaan tersebut memiliki kemampuan untuk membayar seluruh kewajiban lancarnya dan menunjukkan kondisi keuangan yang baik yang dimiliki oleh perusahaan tersebut. Purwaningsih (2013) juga berpendapat bila semakin tinggi rasio likuiditas suatu perusahaan maka akan semakin tinggi pula rating perusahaan tersebut karena semakin besar pula kemampuan perusahaan untuk melunasi seluruh kewajiban lancarnya. I. K. Sari \& Yasa (2016) dan Rusfika \& Wahidahwati (2017) menemukan bahwa likuiditas mempunyai pengaruh negatip signifikan terhadap peringkat obligasi.
H4. Likuiditas berpengaruh positif terhadap prediksi peringkat obligasi.

Semakin tinggi leverage menunjukkan sebagian besar modal yang dimiliki perusahaan didanai oleh hutang, sehingga akan mengakibatkan semakin sulitnya perusahaan untuk memperoleh pinjaman dikarenakan perusahaan berada dalam default risk (Widowati et al., 2013). Default risk ini terjadi karena besar kemungkinan perusahaan tidak dapat mengembalikan pokok pinjaman dan bunga secara berkala yang disebabkan oleh besarnya hutang yang dimiliki perusahaan tersebut. Penelitian Utami \& Khairunnisa (2015) dan Werastuti (2015) menemukan bahwa leverage berpengaruh negatip signifikan terhadap peringkat obligasi.

H5. Leverage berpengaruh negatif terhadap prediksi peringkat obligasi.

\section{Variabel Non Akuntansi dan Peringkat Obligasi}

Obligasi dengan jaminan adalah obligasi yang harus disertai dengan jaminan aktiva tertentu atau dengan jaminan lain dari pihak ketiga (Wijayanti \& Priyadi, 2014). Sementara jenis obligasi tanpa jaminan adalah junk bond yaitu obligasi yang memiliki tingkat bunga sebab memiliki tingkat risiko kredit yang besar. Investor biasanya lebih menyukai obligasi yang 


\section{Nominal: Barometer Riset Akuntansi dan Manajemen}

P-ISSN: 2303-2065 E-ISSN: 2502-5430

Volume 10 No 1 (2021)

dijamin dibandingkan dengan obligasi yang tidak dijamin karena obligasi dengan jaminan memberikan tingkat risiko lebih kecil dan peringkat obligasi yang lebih baik (Utami \& Khairunnisa, 2015). Obligasi dengan jaminan dapat dikategorikan aman. Utami \& Khairunnisa (2015) menyatakan bahwa jaminan obligasi berpengaruh signifikan terhadap peringkat obligasi. Hal ini menunjukkan bahwa peringkat obligasi yang tinggi biasanya dijamin dengan nilai asset yang tinggi juga. Penelitian Sari \& Badjra (2016) dan Rusfika \& Wahidahwati (2017) juga menemukan hasil yang sama bahwa jaminan obligasi berpengaruh positip terhadap peringkat obligasi.

H6. Jaminan obligasi berpengaruh positif terhadap prediksi peringkat obligasi.

Obligasi dengan umur yang lebih singkat atau pendek (misalnya dalam tiga tahun) cenderung lebih mudah diprediksi dibandingkan dengan obligasi yang berumur lebih panjang dari itu (Fauziah, 2014). Obligasi yang semakin mudah diprediksi umumnya memiliki risiko yang lebih kecil dibandingkan dengan obligasi dengan tingkat ketidakpastian yang lebih tinggi. Wendy \& Sianturi (2017) menjelaskan bahwa obligasi dengan maturitas yang lebih pendek cenderung memiliki default risk yang lebih rendah karena faktor uncertainty yang relatif rendah sehingga lebih predictable.
Purwaningsih (2013) menemukan pengaruh negatif antara umur obligasi terhadap peringkat obligasi.

H7. Umur Obligasi berpengaruh negatif terhadap prediksi peringkat obligasi.

Auditor eksternal mempunyai peran penting dalam pengambilan keputusan oleh pemakai laporan keuangan termasuk keputusan yang dibuat oleh investor. Pendapat mengenai kewajaran laporan keuangan berguna sebagai salah satu pertimbangan investor dalam membuat keputusan investasinya, karena auditor eksternal merupakan pihak independen dalam melakukan audit laporan keuangan perusahaan. Laporan keuangan perusahaan yang diaudit oleh auditor yang mempunyai reputasi baik akan memberikan sinyal bagi investor bahwa kualitas laporan keuangan yang disajikan juga berkualitas. Vina (2018) berpendapat bahwa semakin tinggi reputasi auditor diharapkan semakin baik keputusan yang dibuat berdasarkan hasil audit atas laporan keuangan tersebut. Penelitian Widowati et al. (2013) menemukan bahwa reputasi auditor berpengaruh positip terhadap prediksi peringkat obligasi.

H8. Reputasi Auditor berpengaruh positif terhadap prediksi peringkat obligasi. 


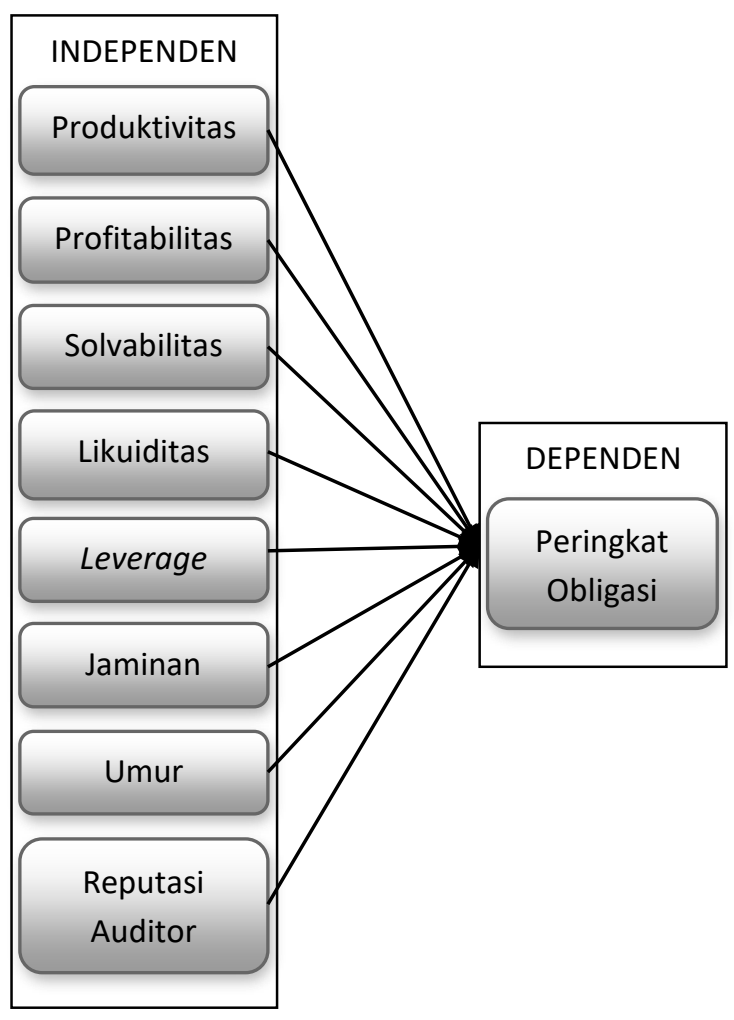

Gambar 1: Model Penelitian

\section{METODE PENELITIAN}

\section{Populasi dan Sampel Penelitian}

Populasi dalam penelitian ini adalah perusahaan non keuangan di Indonesia yang terdaftar di Bursa Efek Indonesia serta menerbitkan obligasi tercatat dalam peringkat obligasi yang dikeluarkan oleh PT Pefindo periode 2013-2016. Dari seluruh populasi yang ada kemudian dilakukan pemilihan sampel dengan metode purposive sampling berdasarkan kriteria: (1) Obligasi perusahaan non keuangan yang terdaftar di Bursa Efek Indonesia berturut-turut selama tahun 2013-2016, (2) Selama periode pengamatan, obligasi tersebut diperingkat oleh PT Pefindo, (3) obligasi perusahaan non keuangan yang menerbitkan laporan tahunan per 31 Desember antara tahun 2013-2016 yang dimuat di www.idx.co.id.

Berdasarkan kriteria tersebut terpilih sampel selama 4 tahun sebanyak 120 obligasi. Adapun proses pemilihan sampel disajikan pada tabel 1 .

Tabel 1: Proses Pemilihan Sampel

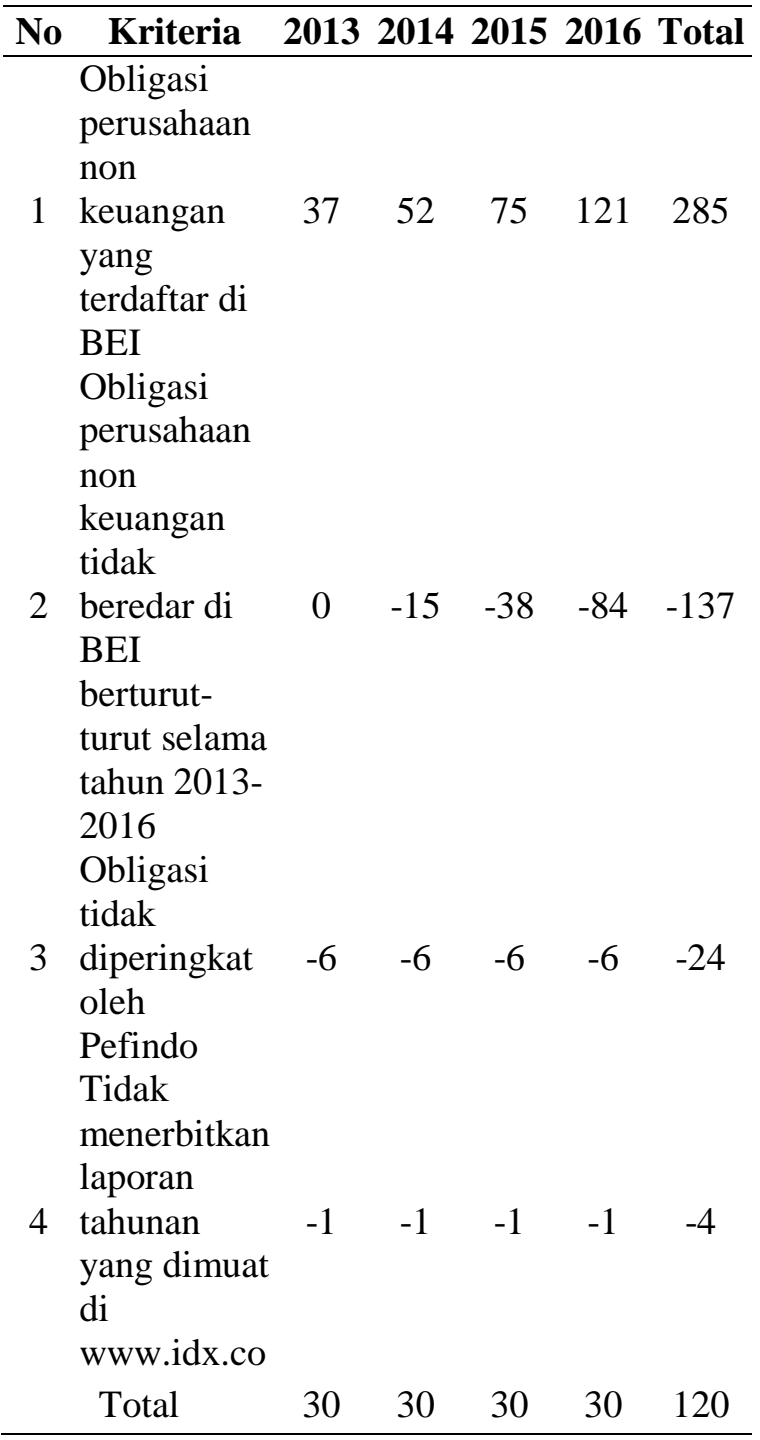

\section{Pengukuran Variabel Penelitian}

Variabel dependen yang digunakan dalam penelitian ini adalah peringkat obligasi yang dikeluarkan oleh PT Pefindo. Blesia \& 
Pramudika (2016) menjelaskan bahwa pengukuran peringkat obligasi menggunakan skala nominal.

Tabel 2: Pengukuran Variabel

\begin{tabular}{|c|c|c|}
\hline Variabel & $\begin{array}{c}\text { Pengukuran } \\
\text { Variabel }\end{array}$ & Referensi \\
\hline \multicolumn{2}{|c|}{ Produktivita $\mathrm{ST}$} & \multirow{2}{*}{$\begin{array}{l}\text { Rusfika \& } \\
\text { Wahidahwa } \\
\text { i (2017) }\end{array}$} \\
\hline$s$ & tal Assets & \\
\hline \multicolumn{2}{|c|}{ Profitabilita $\mathrm{ROA}=$} & \multirow{2}{*}{$\begin{array}{l}\text { Nufita } \\
(2017)\end{array}$} \\
\hline$s$ & $\frac{\text { Earning After Tax }}{\text { Total Assets }}$ & \\
\hline \multirow[t]{2}{*}{ Solvabilitas } & \multirow{2}{*}{\multicolumn{2}{|c|}{$\frac{\text { Cash Flow From operatin }}{\text { Total Assets }}$ i (2017) }} \\
\hline & & \\
\hline Likuiditas & $\begin{array}{l}\text { STA }= \\
\frac{\text { Current Assets }}{\text { Current Liabilities }}\end{array}$ & $\begin{array}{l}\text { Utami \& } \\
\text { Khairunnisa } \\
\text { (2015) }\end{array}$ \\
\hline Leverage & STA $=\frac{\text { Total Liabilities }}{\text { Equity }}$ & $\begin{array}{l}\text { Sari \& } \\
\text { Badjra } \\
(2016)\end{array}$ \\
\hline Jaminan & Variabel dummy, & Purwaningsi \\
\hline Oblig & $\begin{array}{l}\text { kode } 1 \text { menunjukkan } \\
\text { obligasi dengan } \\
\text { jaminan, sedangkan } \\
\text { kode } 0 \text { menunjukkan } \\
\text { obligasi tanpa jaminan }\end{array}$ & $\begin{array}{l}\text { h (2013), } \\
\text { Widowati, } \\
\text { Nugrahanti, } \\
\text { \& Kristanto } \\
\text { (2013), dan } \\
\text { Utami \& } \\
\text { Khairunnisa } \\
\text { (2015) }\end{array}$ \\
\hline Umur & Variabel dummy, & Widowati et \\
\hline Obligasi & $\begin{array}{l}\text { kode } 1 \text { untuk obligasi } \\
\text { mempunyai umur } 1-5 \\
\text { tahun, sedangkan } \\
\text { kode } 2 \text { untuk obligasi } \\
\text { yang mempunyai } \\
\text { umur lebih dari } 5 \\
\text { tahun }\end{array}$ & $\begin{array}{l}\text { al. (2013) } \\
\text { dan Rusfika } \\
\& \\
\text { Wahidahwat } \\
\text { i (2017) }\end{array}$ \\
\hline $\begin{array}{l}\text { Reputasi } \\
\text { Auditor }\end{array}$ & $\begin{array}{l}\text { Variabel dummy, } \\
\text { kode } 1 \text { adalah jika } \\
\text { diaudit oleh KAP The } \\
\text { Big 4, sedangkan kode }\end{array}$ & $\begin{array}{l}\text { Widowati et } \\
\text { al. (2013) } \\
\text { dan Rusfika } \\
\text { \& }\end{array}$ \\
\hline & $\begin{array}{l}0 \text { adalah jika diaudit } \\
\text { oleh selain KAP The } \\
\text { Big Four }\end{array}$ & $\begin{array}{l}\text { Wahidahwat } \\
\text { i (2017) }\end{array}$ \\
\hline
\end{tabular}

Dalam penelitian ini peringkat obligasi menggunakan skala nominal menurut Pefindo (2018), tetapi khusus kategori investment grade dengan 3 klasifikasi nilai, yaitu 3, 2 dan 1 . Tabel 2 menyajikan pengukuran semua variabel independen dalam penelitian ini.

\section{Metode Analisis Data}

Metode analisis data untuk menguji hipotesis dalam penelitian ini adalah ordinal logistic regression. Adapun persamaan regresi logistik ordinal adalah sebagai berikut:

$$
\operatorname{Logit} \operatorname{RATING}(1-3)=\quad \alpha 1 \quad+
$$
$\beta 1 \mathrm{PROD}+\beta 2 \mathrm{PROF}+\beta 3 \mathrm{SOL}+\beta 4 \mathrm{LIKUID}$ $+\beta 5 \mathrm{LEV}+\beta 6 \mathrm{JAM}+\beta 7 \mathrm{UMUR}+$ $\beta 8$ AUDITOR $+\varepsilon$

Keterangan: Logit Rating (variable bond rating dengan 3 kategori, $\alpha$ (konstanta), $\beta$ (koefisien variable, PROD (produktivitas), PROF (profitabilitas), SOL (solvabilitas), LIKUID (likuiditas), LEV (leverage), JAM (jaminan), UMUR (umur obligasi), AUDITOR (reputasi auditor), dan $\varepsilon$ (error term)

\section{HASIL PENELITIAN DAN \\ PEMBAHASAN}

\section{Statistik Deskriptif}

Statistik deskriptif dalam penelitian ini menggambarkan data masing-masing variabel penelitian yang meliputi nilai mean, minimum, maksimum, dan standar deviasi. Hasil statistik deskriptif disajikan pada tabel 3. 
Tabel 3: Statistik Deskriptif

\begin{tabular}{lrrrr}
\hline \multicolumn{1}{l}{ Variable Minimum Maksimum } & Mean & \multicolumn{1}{c}{ SD } \\
\hline PROD & 0,17 & 1,53 & 0,55 & 0,37 \\
PROF & $-10,18$ & 16,24 & 2,88 & 4,94 \\
SOL & $-20,77$ & 72,39 & 9,08 & 15,39 \\
LIKUID & 24,14 & 296,23 & $131,0466,12$ \\
LEV & 44,70 & 2501,16 & $207,2318250,15$
\end{tabular}

Berdasarkan tabel 3 di atas, variabel produktivitas (PROD) mempunyai nilai minimum dan maksimum masing-masing sebesar 0,17 dan 1,53 dengan nilai rata-rata 0,55 dan standar deviasi sebesar 0,37 . Nilai standar deviasi variabel produktivitas yang lebih kecil dari nilai rata-ratanya menandakan bahwa variabel produktivitas ini bersifat cukup homogen.

Variabel profitabilitas

(PROF) mempunyai nilai minimum dan maksimum masing-masing sebesar $-10,18$ dan 16,24 dengan nilai rata-rata 2,8814 sedangkan standar deviasi sebesar 4,94484. Nilai standar deviasi yang lebih besar dari nilai rata-ratanya menandakan bahwa variable profitabilitas ini bersifat heteregon.

Variabel solvabilitas (SOL) mempunyai nilai minimum dan maksimum masingmasing sebesar -20,77 dan 72,39 dengan nilai rata-rata 9,0799 sedangkan standar deviasi sebesar 15,38644. Nilai standar deviasi yang lebih besar dari nilai rata-ratanya menandakan bahwa variable solvabilitas ini bersifat heterogen.

$$
\text { Variabel likuiditas }
$$

(LIKUID) mempunyai nilai minimum dan maksimum masing-masing sebesar 24,14 dan 296,23 dengan nilai rata-rata 131,04 sedangkan standar deviasi sebesar 66,12. Nilai standar deviasi yang lebih kecil dari nilai rataratanya menandakan bahwa variable likuiditas ini bersifat cukup homogen.

Variabel leverage (LEV) mempunyai nilai minimum dan maksimum masingmasing sebesar 44,70 dan 2.501,16 dengan nilai rata-rata 207,2318 sedangkan standar deviasi sebesar 250,14610. Nilai standar deviasi yang lebih besar dari nilai rataratanya menandakan bahwa variable leverage ini bersifat heterogen.

\section{Hasil Analisis Regresi Logistik Ordinal}

Tahap pertama dalam analisis regresi logistic ordinal adalah menguji keseluruhan model (overall model fit). Hasil uji keseluruhan model menunjukkan bahwa nilai -2 Loglikehood pada model intercept only adalah sebesar 177,219 sedangkan ketika variabel independen dimasukkan ke dalam model nilai -2 Loglikehood turun menjadi 131,984 dengan nilai signifikansi sebesar 0,000 sehingga dapat disimpulkan bahwa model secara keseluruhan sesuai dengan data.

Tahap berikutnya adalah dengan melihat melakukan uji kelayakan model regresi logsitik ordinal. Nilai Chi-Square-Pearson adalah dan Chi Square-Deviance masingmasing sebesar 278,277 131,984 dengan nilai signifikansi masing-masing adalah sebesar 


\section{Nominal: Barometer Riset Akuntansi dan Manajemen}

P-ISSN: 2303-2065 E-ISSN: 2502-5430

Volume 10 No 1 (2021)

0,000 dan 0,935 . Nilai signifikansi ChiSquare-Deviance sebsar 0,935 atau lebih besar dari 0,05 maka dapat disimpulkan bahwa model regresi logistic ordinal dalam penelitian ini telah lolos uji kesesuaian model sehingga bisa digunakan sebagai dasar analisis berkutnya.

Pseudo R-Square digunakan untuk mengetahui besarnya variabilitas variabel dependen yang dapat dijelaskan oleh variabel independen dalam penelitian. Nilai McFadden sebesar 0,255 mengindikasikan bahwa perubahan variasi variable peringkat obligasi mampu dijelaskan oleh variabel independen sebesar $25,5 \%$ dan sisanya sebesar 74,5\% dijelaskan oleh variable lain di luar model penelitian.

Uji parallel lines digunakan untuk menilai apakah semua kategori memiliki parameter yang sama atau tidak. Asumsi Parallel Lines dipenuhi apabila nilai yang diperoleh adalah tidak signifikan atau diatas $0,05(\mathrm{p}>\alpha 0,05)$. Nilai Parallel Lines sebesar 0,080 atau diatas 0,05 sehingga bisa disimpulkan bahwa model yang dihasilkan memiliki parameter yang sama atau hubungan antara variabel independen dengan logit adalah sama untuk semua persamaan logit, sehingga pemilihan link function telah sesuai.

Hasil pengujian hipotesis dengan analisis regresi logistic disajikan pada tabel 4.
Tabel 4: Hasil Uji Hipotesis

\begin{tabular}{lrrrr}
\hline \multicolumn{1}{c}{ Variable } & Prediksi Estimate & Wald Sig. \\
\hline (Rating=1) & & $-5,025$ & 23,758 & 0,000 \\
(Rating=2) & & $-1,045$ & 3,774 & 0,052 \\
& & & & \\
& & & & \\
PROD & + & $-0,211$ & 0,174 & 0,677 \\
PROF & + & 0,068 & 1,720 & 0,190 \\
SOL & + & 0,063 & 12,858 & $0,000^{*}$ \\
LIKUID & + & $-0,006$ & 3,785 & $0,052^{* *}$ \\
LEV & - & $-0,002$ & 8,611 & $0,003^{*}$ \\
JAM & + & $-0,111$ & 0,063 & 0,802 \\
UMUR & - & 0,846 & 5,291 & $0,021^{* *}$ \\
AUDITOR & + & $-0,136$ & 0,111 & 0,739 \\
\hline
\end{tabular}

*: signifikan pada level 5\% serta koefisien searah dengan prediksinya.

**: signifikan pada level 5\%, tetapi koefisien berlawanan arah dengan prediksinya.

Tabel 4 di atas menunjukkan hasil estimasi parameter masing masing variabel dalam regresi logistik ordinal. Berdasarkan tabel di atas diperoleh persamaan regresi sebagai berikut:

Logit $(\mathrm{p} 1)=-5,025-0,211 \mathrm{PROD}+$ 0,068PROF + 0,063SOL - 0,006LIKUID 0,002LEV - 0,111JAM + 0,846UMUR 0,136AUDITOR

$$
\begin{gathered}
\text { Logit }(\mathrm{p} 1+\mathrm{p} 2)=-1,045 \\
\text { 0,211PROD + 0,068PROF + 0,063SOL - } \\
\text { 0,006LIKUID - 0,002LEV - 0,111JAM + } \\
\text { 0,846UMUR - 0,136AUDITOR }
\end{gathered}
$$

Hasil pengujian hipotesis menunjukkan bahwa terdapat 2 hipotesis yang didukung, yaitu H3, dan H5. Artinya variable solvabilitas terbukti berpengaruh positif signifikan terhadap prediksi peringkat obligasi, sedangkan leverage mempunyai 
pengaruh negatif signifikan terhadap prediksi peringkat obliasi. Pengujian terhadap hipotesis 7 (H7) justru memberikan hasil yang berlawanan dengan prediksinya, yaitu umur obligasi justru ditemukan berpengaruh

positif signifikan terhadap peringkat obliasi. Sementara 5 variabel yang lain yaitu produktivitas, likuiditas, jaminan obligasi dan reputasi auditor tidak terbukti berpengaruh terhaadap prediksi peringkat obligaasi pada perusahaan non keuangan di Indonesia. Berikut ini pembahasan hasil pengujian hipotesis:

\section{Produktivitas dan Peringkat Obligasi}

Hasil pengujian hipotesis 1 (H1) menunjukkan bahwa produktivitas (PROD) yang diproksikan dengan Sales to Assets (STA) memiliki nilai sebesar -0,211 dengan tingkat signifikansi 0,677 dan nilai statistik wald sebesar 0,174 . Artinya bahwa H1 tidak berhasil didukung.

Penelitian ini tidak konsisten dengan hasil penelitian Henny (2016) yang menyatakan bahwa produktivitas cenderung berpengaruh signifikan positif terhadap peringkat obligasi. Namun, hasil penelitian ini konsisten dengan penelitian Rusfika \& Wahidahwati (2017) dan Widowati et al. (2013) yang menemukan bahwa produktivitas perusahaan tidak mempunyai pengaruh signifikan terhadap peringkat obligasi. Penyebab kemungkinan produktivitas tidak dapat dijadikan faktor dalam memprediksi peringkat obligasi dalam penelitian ini karena perbedaan sektor perusahaan yang digunakan pada penelitian ini dengan penelitian sebelumnya sehingga penilaian tentang tinggi rendahnya produktivitas itu berbeda antara sektor satu dengan yang lainnya.

\section{Profitabilitas dan Peringkat Obligasi}

Hasil pengujian hipotesis 2 menunjukkan bahwa profitabilitas (PROF) yang diproksikan dengan Return on Assets (ROA) memiliki nilai koefisien positif sebesar 0,068 dengan tingkat signifikansi 0,190 dan nilai statistik wald sebesar 1,720. Artinya bahwa $\mathrm{H} 2$ tidak berhasil didukung.

Penelitian ini tidak konsisten dengan hasil penelitian Amalia (2013), Rusfika \& Wahidahwati (2017) dan Widowati et al. (2013) yang menyatakan bahwa produktivitas cenderung berpengaruh signifikan positif terhadap peringkat obligasi. Namun, hasil penelitian ini konsisten dengan penelitian Utami \& Khairunnisa (2015) dan I. K. Sari \& Yasa (2016) yang menyimpulkan bahwa variabel profitabilitas tidak berpengaruh signifikan terhadap peringkat obligasi.

Rasio profitabilitas dalam penelitian ini tidak memengaruhi dalam prediksi peringkat obligasi. Hal ini kemungkinan disebabkan karena nilai rata-rata ROA perusahaan sampel selama periode pengamatan sebesar $2,88 \%$ merupakan angka yang tergolong 


\section{Nominal: Barometer Riset Akuntansi dan Manajemen}

P-ISSN: 2303-2065 E-ISSN: 2502-5430

Volume 10 No 1 (2021)

rendah sehingga nilai ROA dalam penelitian ini belum mampu digunakan untuk memprediksi peringkat obligasi pada perusahaan non keuangan di Indonesia. Oleh karena itu Profitabilitas yang menunjukkan kemampuan perusahaan menghasilkan laba dalam penelitian ini tidak bisa dijadikan acuan dalam menilai peringkat obligasi yang diterbitkan perusahaan non keuangan di Indonesia.

\section{Solvabilitas dan Peringkat Obligasi}

Hasil pengujian hipotesis 3 (H3) menunjukkan bahwa solvabilitas (SOL) yang diproksikan dengan Cash Flow From Operating (CFOTL) memiliki nilai koefisien positif sebesar 0,063 dengan tingkat signifikansi 0,000 dan nilai statistik wald sebesar 12,858. Artinya bahwa H3 berhasil didukung. Hasil penelitian ini konsisten dengan penelitian Rusfika \& Wahidahwati (2017) dan Widowati et al. (2013) yang menemukan bahwa variabel solvabilitas mempunyai pengaruh positif signifikan terhadap peringkat obligasi.

Solvabilitas yang diproksikan dengan Cash Flow From Operating (CFOTL) menunjukkan bahwa arus kas dari aktivitas operasi mampu digunakan untuk melunasi kewajiban jangka panjang dan jangka pendek perusahaan. Artinya bahwa semakin tinggi nilai aliran kas dari aktivitas operasi maka semakin tinggi nilai solvabilitas sehingga nilai solvabilitas yang tinggi ini membuat peringkat obligasi perusahaan semakin tinggi. Nilai solvabilitas yang tinggi membuat peringkat obligasi perusahaan semakin baik karena perusahaan dianggap mampu melunasi semua kewajibannya. Sebaliknya, semakin kecil nilai rasio solvabilitas maka semakin rendah tingkat fleksibilitas keuangan perusahaan sehingga akan meningkatkan kemungkinan perusahaan menghadapi masalah finansial dimasa yang akan datang.

\section{Likuiditas dan Peringkat Obligasi}

Hasil pengujian hipotesis 4 (H4) menunjukkan bahwa likuiditas yang diproksikan dengan Current Ratio (CR) memiliki koefisien sebesar -0,006 dengan tingkat signifikansi 0,052 dan nilai statistik wald sebesar 3,785. Untuk pengujian hipotesis satu sisi, maka variabel Current Ratio ini dapat disimpulkan mempunyai pengaruh negatip signifikan terhadap peringkat obligasi pada perusahaan non keuangan di Indonesia. Hasil ini berarti $\mathrm{H} 4$ tidak berhasil didukung, karena hasil pengujian hipotesis mempunyai arah yang berlawanan dengan prediksinya. Hasil ini mengindikasikan bahwa semakin tinggi likuiditas perusahaan, maka peringkat obligasi pada perusahaan non keuangan di Indonesia justru semakin rendah, demikian sebaliknya.

Penelitian ini tidak konsisten dengan hasil penelitian I. K. Sari \& Yasa (2016) serta 


\section{Nominal: Barometer Riset Akuntansi dan Manajemen}

P-ISSN: 2303-2065 E-ISSN: 2502-5430

Volume 10 No 1 (2021)

Rusfika \& Wahidahwati (2017) yang menyatakan bahwa likuiditas cenderung berpengaruh signifikan positif terhadap peringkat obligasi. Hasil penelitian yang berlawanan dengan hipotesis ini menunjukkan bahwasannya perusahaan yang mempunyai tingkat likuiditas yang tinggi cenderung tidak tertarik untuk menerbitkan obligasi. Hal ini kemungkinan disebabkan karena perusahaan yang likuiditasnya tinggi mempunyai dana dari internal perusahaan yang cukup sehingga kemungkinan besar perusahaan memilih memakai dana dari internal perusahaan terlebih dulu dibandingkan menggunakan sumber dana dari pihal eksternal perusahaan misalnya dengan menerbitkan obligasi. Penerbitan obligasi yang dilakukan oleh perusahaan yang mempunyai likuiditas yang tinggi justru akan berdampak terhadap nilai perusahaan lebih memburuk yang pada akhirnya juga memiliki pengaruh terhadap peringkat obligasi yang memburuk. Hasil penelitian ini sesuai dengan penelitian yang dilakukan oleh Manurung, S, \& T (2009) dan Dali, Ronni, \& Malelak (2015) yang menunjukkan bahwa likuiditas berpengaruh negatif signifikan terhadap peringkat obligasi.

\section{Leverage dan Peringkat Obligasi}

Hasil pengujian hipotesis 5 (H5) menunjukkan bahwa leverage (LEV) yang diproksikan dengan Debt To Equity Ratio (DER) memiliki nilai koefisien sebesar -
0,002 dengan tingkat signifikansi 0,003 dan nilai statistik wald sebesar 8,611. Artinya bahwa Ha5 berhasil didukung. Hasil ini sesuai dengan temuan Werastuti (2015) serta Utami \& Khairunnisa (2015) yang menyimpulkan bahwa variabel leverage berpengaruh negatip signifikan terhadap peringkat obligasi.

Hasil penelitian ini mengindikasikan bahwa semakin rendah nilai leverage berarti perusahaan memiliki kemampuan tinggi dalam menjamin hutang jangka pendek dan jangka panjangnya dengan menggunakan modal yang tersedia. Perusahaan yang memiliki jumlah hutang yang lebih kecil dari jumlah modal dapat diartikan bahwa perusahaan mampu melunasi hutang dengan menggunakan modal yang dimiliki. Perusahaan yang mampu mengelola hutang dengan baik kemungkinan besar akan mempunyai kemampuan menghasilkan laba yang besar juga. Peningkatan laba yang diperoleh akan berdampak pada peningkatan modal perusahaan. Kondisi perusahaan seperti ini kemungkinan akan lebih banyak diminati investor karena pada umumnya perusahaan seperti ini memiliki peringkat obligasi yang baik juga.

\section{Jaminan dan Peringkat Obligasi}

Hasil pengujian hipotesis 6 (H6) menunjukkan bahwa jaminan (JAM) memiliki nilai koefisien sebesar $-0,111$ dengan tingkat signifikansi 0,802 dan nilai 
statistik wald sebesar 0,063. Artinya bahwa H6 tidak berhasil didukung.

Penelitian ini tidak konsisten dengan hasil penelitian Utami \& Khairunnisa (2015), Sari \& Badjra (2016), serta (Rusfika \& Wahidahwati, 2017) yang menyimpulkan bahwa besarnya jaminan cenderung mendorong peningkatan peringkat obligasi. Namun, hasil penelitian ini sesuai dengan penelitian Widowati et al. (2013) serta Blesia \& Pramudika (2016) yang menyimpulkan bahwa variabel jaminan tidak berpengaruh terhadap peringkat obligasi.

Jaminan dalam penelitian ini tidak memberikan pengaruh pada peringkat obligasi kemungkinan disebabkan investor obligasi tidak menjadikan jaminan ini sebagai faktor penting dalam membuat keputusan investasinya. Fenomena tersebut didukung data pada PT AKR Corporindo Tbk dan PT. Indosat Tbk yang keduanya menerbitkan obligasi tanpa jaminan tetapi memiliki peringkat obligasi dengan kategori investment grade dengan nilai 3. Hasil ini mengindikasikan bahwa meskipun obligasi yang diterbitkan perusahaan merupakan obligasi tanpa jaminan tetapi jika perusahaan memberikan imbal hasil yang tinggi pada investor maka kemungkinan tetap tertarik untuk melakukan investasi karena kemungkinan peringkat obligasi tersebut cukup tinggi yang menandakan kemampuan perusahaan membayar kewajibannya juga tinggi.

\section{Pengaruh Umur terhadap Peringkat Obligasi}

Umur obligasi (UMUR) memiliki nilai koefisien positif sebesar 0,846 dengan nilai signifikansi 0,021 dan statistik wald sebesar 5,291. Artinya bahwa H7 tidak berhasil didukung, karena memiliki arah yang berlawanan dengan prediksinya. Hasil penelitian ini tidak konsisten dengan penelitian Purwaningsih (2013) yang menemukan pengaruh negatip antara umur obligasi dengan peringkat obligasi. Hasil penelitian ini justru menunjukkan fenomena bahwa semakin lama umur obligasi maka akan semakin baik peringkat obligasi. Temuan ini kemungkinan disebabkan karena investor mempunyai keyakinan yang cukup tinggi bahwa perusahaan penerbit akan mampu membayar bunga periodik dan pokok pinjaman pada saat jatuh tempo obligasinya, meskipun jangka waktu pembayaran pokok obligasi pada saat jatuh tempo cukup lama. Kemungkinan yang lain adalah bahwa investor mempunyai keyakinan yang cukup besar jika mereka bisa menjual investasi obligasinya setiap saat ketika mereka membutuhkan dana. Oleh karena itu obligasi yang umurnya lama justru semakin menarik bagi investor untuk berinvestasi karena memberikan harapan atas return yang semakin besar yang akan diperoleh selama 


\section{Nominal: Barometer Riset Akuntansi dan Manajemen}

P-ISSN: 2303-2065 E-ISSN: 2502-5430

Volume 10 No 1 (2021)

umur obligasi tersebut. Fenomena ini yang kemungkinan menjadi faktor yang mendorong peningkatan peringkat obligasi yang diterbitkan oleh perusahaan non keuangan di Indonesia.

\section{Reputasi Auditor dan Peringkat Obligasi}

Hasil pengujian hipotesis 8 (H8) menunjukkan bahwa Reputasi auditor (AUDITOR) memiliki nilai koefisien sebesar $-0,136$ dengan tingkat signifikansi 0,739 dan nilai statistik wald sebesar 0,111 . Artinya bahwa H8 tidak berhasil didukung. Hasil penelitian ini tidak konsisten dengan penelitian Widowati et al. (2013) yang menemukan bahwa reputasi auditor mempunyai pengaruh positip signifikan terhadap peringkat obligasi. Namun hasil ini sesuai dengan penelitian Blesia \& Pramudika (2016) dan Rusfika \& Wahidahwati (2017) yang menyatakan bahwa reputasi auditor tidak mempunyai pengaruh terhadap prediksi peringkat obligasi. Tidak berpengaruhnya variable reputasi auditor terhadap prediksi peringkat obligasi ini kemungkinan disebabkan karena pembedaan auditor yang berafiliasi pada KAP Big 4 dan non big 4 tidak cukup menjadi ukuran baik buruknya reputasi auditor yang bersangkutan. Dengan demikian perusahaan yang diaudit oleh KAP big 4 tidak menjamin bahwa obligasi yang diterbitkan memiliki peringkat investment grade, demikian sebaliknya perusahaan yang diaudit oleh KAP non big 4 belum tentu obligasi yang diterbitkannya memperoleh peringkat non investment grade.

\section{SIMPULAN DAN SARAN}

Penelitian ini mempunyai keterbatasan antara lain adalah yang pertama nilai Adj R2 sebesar $25,5 \%$, artinya bahwa hanya $25,5 \%$ variabel peringkat obligasi yang dapat dijelaskan oleh variabel independen dalam model. Sisanya sebesar $74,5 \%$ dijelaskan oleh variabel-variabel lain di luar model penelitian. Oleh karena itu, penelitian selanjutnya diharapkan dapat menambahkan faktor akuntansi yang lain, misalnya rasio cakupan bunga dan risiko bisnis dan faktor non akuntansi yang lain, misalnya kebijakan akuntansi, faktor lingkungan, dan peraturan yang berkaitan dengan perusahaan.

Keterbatasan lainnya adalah bahwa penelitian ini hanya berdasarkan peringkat yang berikan oleh PT Pefindo, sehingga tidak diketahui bagaimana penilaian obligasi yang diperingkat oleh lembaga pemeringkat selain PT Pefindo. Oleh karena itu diharapkan penelitian selanjutnya dapat menggunakan data peringkat obligasi dari lembaga pemeringkat lain yaitu PT Kasnic Credit Rating Indonesia dan PT Fitch Rating Indonesia yang belum diteliti pada sampel penelitian ini. Kemudian dapat dilakukan uji beda untuk membandingkan hasil penelitian 
dengan menggunakan data dari lembaga pemeringkat selain Pefindo tersebut.

Perusahaan non keuangan di Indonesia diharapkan agar selalu memperbaiki kinerja akuntansi maupun non akuntansinya sehingga kepercayaan investor maupun kreditor terhadap obligasi yang diterbitkan perusahaan juga semakin meningkat. Dengan semakin meningkatnya kepercayaan investor maupun kreditor terhadap obligasi yang diterbitkan perusahaan maka akan berdampak pada peningkatan peringkat obligasi tersebut.

\section{DAFTAR PUSTAKA}

Amalia, N. (2013). Pemeringkatan Obligasi PT Pefindo: Berdasarkan Informasi Keuangan. Accounting Analysis Journal, 2(2), 139-147.

Blesia, J. U., \& Pramudika, D. R. (2016). Key Aspects of the Bond Ratings in Indonesia. Asian Journal of Economics, Business and Accounting, 1(3), 1-14.

Dali, C. L., Ronni, S., \& Malelak, M. I. (2015). Pengaruh Mekanisme Corporate Governance dan Rasio Keuangan terhadap Peringkat Obligasi. FINESTA, 3(1), 30-35.

Fauziah, Y. (2014). Pengaruh Likuiditas, Leverage, dan Umur Obligasi Terhadap Peringkat Obligasi Perusahaan (Studi Empiris pada Perusahaan yang Terdaftar di Bursa Efek Indonesia). Jurnal Akuntansi, 2(1).

Henny. (2016). Pengaruh Faktor Akuntansi Terhadap Prediksi peringkat Oblikasi. Jurnal Akuntansi, 20(1), 52-69.
Manurung, A., S, D., \& T, W. (2009). Hubungan Rasio-Rasio Keuangan dengan Rating Obligasi. Jurnal Finansial Dan Bisnis, 2(1), 34-48.

Melani, A. (2016). Operator Taksi Express Gagal Bayar Bunga Utang.

Nufita, I. (2017). Pengaruh Afiliasi Kap Tahun Lalu, Profitabilitas, Dan Sistem Pengendalian Internal Terhadap Audit Report Lag Dengan Audit Tenure Sebagai Variabel Pemoderasi. Universitas Negeri Yogyakarta.

Pefindo. (2018). Rating Methodology.

Purwaningsih, S. (2013). Faktor Yang Mempengaruhi Rating Sukuk Yang Ditinjau Dari Faktor Akuntansi Dan Non-Akuntansi. Accounting Analysis Journal, 2(3).

Rusfika, \& Wahidahwati. (2017) Kemampuan Faktor Akuntansi Dan Non Akuntansi Dalam Memprediksi Bond Rating. Jurnal Ilmu Dan Riset Akuntansi, 1, 85-103.

Sari, I. K., \& Yasa, G. W. (2016). Pengaruh Penerapan Good Corporate Governance, Profitabilitas dan Likuiditas terhadap peringkat Obligasi. E-Jurnal Akuntansii, 17(3), 2198-2224.

Sari, N. M. S. K., \& Badjra, I. B. (2016). Pengaruh Likuiditas, Ukuran Perusahaan, Leverage, dan Jaminan Terhadap Peringkat Obligasi Pada Sektor Keuangan. E-Jurnal Manajemen Universitas Udayana, 5(8), 5041-5069.

Spence, M. (1973). Job Marketing Signaling. The Quarterly Journal of Economics, 87(3), 355-374.

Susilowati, S., \& Sumarto. (2010). Memprediksi Tingkat Obligasi Perusahaan Manufaktur yang Listing di BEI. Jurnal Mitra Ekonomi Dan Manajemen Bisnis, 1(2), 163-175. 
Utami, T. C., \& Khairunnisa. (2015). Pengaruh Ukuran Perusahaan, Profitabilitas, Leverage, Likuiditas Dan Jaminan Obligasi Terhadap Peringkat Obligasi (Studi Pada Perusahaan Yang Terdaftar Di PT. Pefindo (Tahun 20102013). E-Proceeding of Management, 2(3), 3475-3482.

Vina, V. (2018). Analisis Pengaruh Reputasi Auditor, Umur Obligasi, Likuiditas, Growth, Dan Produktivitas Perusahaan Terhadap Peringkat Obligasi Pada Pertumbuhan Go Public Yang Terdaftar Di Bursa. Jurnal Akuntansi Dan Bisnis, 15(30), 104-125.

Wendy, \& Sianturi, R. N. (2017). Bond Ratings dan Antesedennya: Studi Empiris di Bursa Efek Indonesia. Jurnal Ekonomi Bisnis Dan Kewirausahaan, 6(1), 59-70.

Werastuti, D. N. S. (2015). Analisis Prediksi Peringkat Obligasi Perusahaan Dengan Pendekatan Faktor Keuangan dan Non Keuangan. Jurnal Dinamika Akuntansi, 7(1), 63-74.

Widiyastuti, T. (2016). Faktor-Faktor Yang Berpengaruh Terhadap Peringkat Obligasi (Studi Pada Perusahaan Perusahaan Manufaktur Yang Terdaftar di BEI). Jurnal Ilmu Ekonomi, Manajemen, Dan Akutansi, 5(2), 81-91.

Widiyastuti, T., Djumahir, \& Khusniyah, N. (2014). Faktor-faktor yang Berpengaruh terhadap Peringkat Obligasi (Studi pada perusahaan Manufaktur yang terdaftar di BEI). Jurnal Aplikasi Manajemen, 12(2), 269-278.

Widowati, D., Nugrahanti, Y., \& Kristanto, A. B. (2013). Analisis Faktor Keuangan dan Non Keuangan Yang Berpengaruh Pada Prediksi Peringkat Obligasi di Indonesia (Studi Pada Perusahaan Non Keuangan yang Terdaftar di BEI dan di Daftar Peringkat PT Pefindo 20092011). Jurnal Manajemen, 13(1), 35-
53.

Wijayanti, I., \& Priyadi, M. P. (2014). Faktor-Faktor yang Mempengaruhi Peringkat Obligasi. Jurnal Ilmu \& Riset Akuntansi. Jurnal Ilmu Dan Riset Akuntansi, 3(3), 1-15. 